\title{
SIFAT ANTI RAYAP DARI EKSTRAK IJUK AREN (Arenga pinnata Merr.)
}

\author{
Antitermicidal Activities of Sugar- Palm Tree Fibers Extract \\ Astuti Arif, M. Natsir Usman dan Fatmawaty Samma
}

\begin{abstract}
The fiber of sugar-palm tree Arenga pinnata Merr., locally known as ijuk, is frequently harvested after the tree age of 5 years and traditionally used as covering to protect ground-contact wood construction materials against organism attack, particularly subterranean termites. The effectiveness of sufar-palm tree fiber extract of marketed formation using acetone and and hexane againts subterannean termites (Coptotermes sp.) has been observed. The results showed that mortality of termite after 2 weeks is $100 \%$ on samples given the sugar-palm tree fiber extract, compared with the mortality of controls (without sugarpalm tree fiber extract) is $7,07 \%$ after 3 weeks. The consumption rate of termites opposited with the mortality value, due to the existence of bioactive components or chemical compounds having inhibitor or toxic against termites activities.
\end{abstract}

Key words: Sugar-Palm Tree Fiber, Arenga pinnata, Antitermiticidal activities, Coptotermes sp.

\section{PENDAHULUAN}

Upaya untuk memperpanjang masa pakai kayu, terutama jenis kayu berkelas awet rendah (kelas III-V) yang jumlah mencapai $85,7 \%$ dari 4000 jenis kayu yang dikenal di Indonesia (Martawijaya, 1996) memerlukan tindakan pengawetan untuk mencegah dari agen perusak kayu. Organisme yang paling banyak ditemukan menimbulkan kerusakan pada kayu khususnya bangunan adalah rayap tanah. Genus Coptotermes merupakan hama isopteran yang sangat destruktif menyerang kayu dan bahan berkayu di dunia (Takematsu, et.al., 2006) dan berbagai species rayap ini ditemukan di Indonesia, seperti di Pulau Jawa, Sulawesi dan Sumatera. Kerugian akibat serangan rayap pada bangunan/rumah masyarakat di Indonesia diperkirakan telah mencapai 1,67 trilyun per tahun (Rakhmawati, 1996). Di samping itu, data yang dikemukan oleh Supriana (2002) menunjukkan bahwa kerugian dengan adanya serangan rayap bangunan gedung milik pemerintah mencapai 100 milyar rupiah per tahun.

Umumnya bahan pengawet kayu berupa garam-garam larut air yang mengandung tembaga, krom, asam, fenol, seng atau khlor atau senyawa berupa minyak (Sari dan Sutjipto, 2003) dan semua bahan ini berpotensi mencemari lingkungan. Salah satu upaya untuk menghindari pencemaran ini adalah penggunaan bahan-bahan alami dari tumbuh-tumbuhan sebagai bahan pengawet. Ekstrak dari tumbuh-tumbuhan, seperti dari kayu, kulit, daun, bunga, buah atau biji, diyakini berpotensi mencegah pertumbuhan jamur ataupun menolak kehadiran serangga perusak seperti rayap. Hasil penelitian Sari, dkk., (2003) tentang bioaktif anti rayap dari ekstrak resin damar mata kucing dari Shorea javanica menunjukkan bahwa fraksi n-heksana dan fraksi dietil eter diduga mengandung senyawa bioaktif yang bersifat racun terhadap rayap. Senyawa bioaktif yang terkandung dalam kedua fraksi tersebut diduga memiliki peranan yang sangat besar dalam meningkatkan sifat anti rayap ekstrak kasar aseton dalam mematikan rayap. Senyawa-senyawa bioaktif tersebut juga dapat merusak sistem saraf rayap menyebabkan sistem saraf tidak berfungsi dan pada akhirnya dapat mematikan rayap. Menurut Sastrodihardjo (1999), pengaruh zat ekstraktif terhadap kematian rayap dan serangga lainnya adalah sebagai penghambat sintesis protein, khususnya dari kelompok tanin, stilbena, alkaloid, dan resin, sedangkan kelompok terpenoid dapat merusak fungsi sel rayap yang pada akhirnya menghambat proses ganti kulit rayap

Usaha-usaha untuk meneliti efektifitas bahan alam sebagai bahan anti rayap semakin banyak dilakukan. Di daerah pedalaman Sulawesi Selatan, ijuk sering dimanfaatkan untuk melindungi kayu bangunan terhadap serangan rayap. Pada pohon aren, ijuk berperan untuk mencegah masuknya debu dan semut-semut pada celah-celah di antara tongkol bunga aren dan tepi lumbung bambu pada penyadapan nira aren (Soeseno, 1993). Penelitian tentang ijuk 
sebagai perintang fisik telah dilakukan oleh Irfan (2005) menunjukkan bahwa perintang fisik berupa ijuk pasaran dan alami efektif digunakan sebagai bahan alternatif pencegah serangan rayap tanah. Namun, kemampuan ijuk secara kimiawi sebagai bahan antirayap belum diketahui, sehingga penelitian ini dianggap perlu dilakukan.

\section{BAHAN DAN METODE}

\section{Bahan}

Bahan ijuk yang diperoleh di pasaran sebanyak 1 gulungan diserbuk menggunakan hammermill, rayap tanah (Coptotermes sp.), aseton $\left(\mathrm{C}_{3} \mathrm{H}_{6} \mathrm{O}\right)$ dan n-heksana $\left(\mathrm{C}_{6} \mathrm{H}_{14}\right)$, aquadest, kertas saring (Whatman 40 , diameter $12,5 \mathrm{~cm}$ ).

\section{Ekstraksi Sampel}

Serbuk ijuk sebanyak 150 gram diekstraksi dengan aseton dengan perbandingan berat serbuk dan berat aseton 1 : 3 selama 48 jam dan dilakukan berulangkali sampai dihasilkan larutan ekstrak yang jernih. Larutan ekstrak dalam aseton dievaporasi pada suhu $30-40^{\circ} \mathrm{C}$ hingga diperoleh larutan sebanyak $100 \mathrm{ml}$, kemudian ditambahkan $75 \mathrm{ml} \mathrm{n}$-heksana dan $25 \mathrm{ml}$ aquadest lalu dikocok. Fraksi n-heksana terlarut dipisahkan dari fraksi tak terlarut (residu). Fraksi terlarut diuapkan pada suhu $30-40{ }^{\circ} \mathrm{C}$ untuk memperoleh ekstrak kering. Ekstrak kering ini kemudian dilarutkan dalam n-heksana hingga $50 \mathrm{ml}$ untuk tujuan efektivitas sebagai anti rayap. Residu hasil fraksinasi n-heksana juga dipersiapkan $50 \mathrm{ml}$ untuk uji efektivitasnya sebagai anti rayap.

\section{Pengujian Antirayap}

Contoh uji yang digunakan adalah kertas saring (Whatman 40, diameter $12,5 \mathrm{~cm}$ ). Kertas saring direndam dalam larutan ekstrak selama 24 jam lalu dikeringudarakan. Kertas saring tanpa ekstrak (kontrol), kertas saring yang telah direndam dalam ekstrak dari fraksi terlarut dan fraksi tak terlarut (residu) ditimbang untuk memperoleh berat awal (Wo). Pengujian antirayap dilakukan dengan memasukkan contoh uji ke dalam cawan petri. Sebanyak 150 ekor rayap dari kasta pekerja dan 15 ekor dari kasta prajurit yang sehat dan aktif dimasukkan ke dalam setiap contoh uji. Unit pengujian tersebut diletakkan pada suatu wadah yang lebih besar lalu dibiarkan ditempat gelap dan dipertahankan pada suhu $\pm 28^{\circ} \mathrm{C}$ dan kelembaban $\pm 75 \%$ selama 3 minggu. Kelembaban dipertahankan dengan cara penyemprotan aquadest pada kertas uji secukupnya setiap hari. Perhitungan mortalitas dilakukan setiap minggu. Rayap yang mati bangkainya dibuang untuk menghindari adanya konsumsi terhadap rayap lainnya atau sifat kanibalisme rayap. Total rayap yang mati (a) digunakan untuk menghitung persentase mortalitas rayap (M) dari total keseluruhan rayap yang diujikan (b). Pada akhir pengamatan, kertas saring ditimbang untuk menghitung laju konsumsi rayap. Mortalitas dan Laju konsumsi dihitung menggunakan rumus sebagai berikut:

Mortalitas $(\%)=a / b \times 100$

Laju konsumsi rayap (mg/rayap/hari)

$$
=\frac{\text { Jumlah contoh uji yang dimakan }}{\text { Total hari dari rayap pekerja }}
$$

Di mana:

Jumlah contoh uji yang dimakan

$$
=\text { Wo-W } 1
$$

Total hari rayap pekerja

$$
\begin{aligned}
= & \text { Total hari rayap x } 150-(\text { Total } \\
& \text { hari rayap x } 150 \text { x M) / } 2
\end{aligned}
$$

\section{HASIL DAN PEMBAHASAN}

\section{Mortalitas Rayap Tanah}

Nilai persentase mortalitas rayap Coptotermes sp. selama 21 hari pengamatan pada kontrol berkisar 6,06-8,48\% dan pada perlakuan pemberian ekstrak dari fraksi terlarut nheksana dan fraksi residu mencapai 100\% pada hari ke-14. Adapun rata-rata persentase mortalitas dapat dilihat pada Tabel 1. Hasil analisis ragam menunjukkan perlakuan pemberian ekstraksi berpengaruh sangat nyata terhadap mortalitas rayap tanah, dengan hasil uji tukey disajikan pada Tabel 1. Hasil uji menunjukkan nilai mortalitas rayap kontrol berbeda sangat nyata terhadap perlakuan lainnya, sedangkan pada perlakuan pemberian fraksi terlarut $n$-heksana berbeda tidak nyata dengan perlakuan fraksi tak terlarut n-heksana. 
Table 1. Average of termite mortality and Tukey's test

\begin{tabular}{lcc}
\hline Treatments & Termite Mortality $(\%)$ & Tukey'test $(1,45)$ \\
\hline Control & 7,07 & $\mathrm{a}$ \\
Samples soaked with n-hexane-soluble fraction & 100 & $\mathrm{~b}$ \\
Samples soaked with n-hexane-insoluble fraction & 100 & $\mathrm{~b}$ \\
(residu) & & \\
\hline
\end{tabular}

Nilai persentase mortalitas rayap yang tinggi dengan adanya penggunaan ekstrak ijuk diduga disebabkan oleh interaksi kimia yang terjadi antara rayap dengan ekstrak ijuk. ljuk tersebut diduga mengandung bahan yang beracun yang dapat mematikan rayap. Hasil pengamatan pada uji laboratorium terlihat rayap tanah setelah kontak dengan ekstrak memperlihatkan gejala kejang-kejang dan jalan yang tidak beraturan. Ini menunjukkan senyawa yang dikandung oleh ekstrak bekerja secara depresan pada sistem saraf. Gejala ini yang dinyatakan oleh Widianto (1992) sebagai akibat terjadinya penghambatan biosintesis yang menyebabakan kejang-kejang dan efek relaksasi sentral. Karena tubuh yang lunak, maka memudahkan ekstrak masuk ke dalam tubuh melalui dinding tubuh secara kontak. Ada beberapa kemungkinan mekanisme kematian rayap yang diakibatkan oleh senyawa bioaktif yang terdapat dalam ekstrak ijuk. Kemungkinan pertama adalah senyawa bioaktif mematikan protozoa yang merupakan simbion rayap dalam mendekomposisi selulosa didalam perut rayap. Kematian protozoa menyebabkan aktivitas enzim selulase yang dikeluarkan protozoa tersebut terganggu. Hal ini dapat menyebabkan rayap tidak memperoleh makanan dan energi yang dibutuhkan sehingga rayap tersebut mati. Kemungkinan kedua adalah senyawa bioaktof tersebut merusak sistem saraf yang menyebabkan sistem saraf tidak berfungsi dan pada akhirnya akan mematikan rayap.

\section{Laju Konsumsi Rayap}

Nilai laju konsumsi rayap selama 21 hari pengamtan berkisar $0,1252-0,1538 \mathrm{mg} /$ rayap/ hari pada kontrol, 0,0300-0,0802 mg/rayap/hari pada pemberian ekstraksi fraksi terlarut $\mathrm{n}$-heksana, 0,0351-0,0652 $\mathrm{mg} /$ rayap/hari, dengan rata-rata dapat dilihat pada Tabel 2. Hasil analisis ragam menunjukkan perlakuan pemberian ekstrak ijuk pada laju konsumsi rayap berpengaruh sangat nyata, dengan uji tukey seperti disajikan pada Tabel 2. Hasil uji menunjukkan bahwa nilai laju konsumsi rayap pada kontrol berbeda sangat nyata dengan perlakuan pemberian ekstrak ijuk, dimana kedua perlakuan pemberian ekstrak baik dari fraksi terlarut maupun fraksi residu berbeda tidak nyata. Penurunan laju konsumsi rayap karena penggunaan ekstrak ijuk mengindikasikan bahwa ekstrak ijuk yang ditambahkan tersebut kemungkinan mempunyai daya racun. Apabila kehilangan berat contoh uji kecil maka berarti penghambat aktivitas makannya tinggi. Hal ini didiga disebabkan protozoa yang berperan dalam merombak polimer selulosa tidak dapat bekerja dengan baik sehingga rayap tidak memperoleh suplai makanan. Setelah ekstrak masuk ke dalam tubuh rayap menyebabkan dispersi poliribosom dan selanjutnya reticulum endoplasma kasar dihancurkan dalam gelembung yang dilarutkan ke dalam sel dan membengkak, nukleus menjadi rusak dan seluruh saraf menjadi kacau balau.

Table 2. Average of Termite Consumption rate and Tukey's test

\begin{tabular}{lcc}
\hline \multicolumn{1}{c}{ Treatments } & $\begin{array}{c}\text { Consumption Rate Average of } \\
\text { Termite }\end{array}$ (mg/individu/day) & Tukey' test $(0,147)$ \\
\hline Control & 0,1411 & $\mathrm{a}$ \\
Samples soaked with n-hexane-soluble & 0,0618 & $\mathrm{~b}$ \\
fraction & 0,0485 & $\mathrm{~b}$ \\
$\begin{array}{l}\text { Samples soaked with } \mathrm{n} \text {-hexane-insoluble } \\
\text { fraction (residu) }\end{array}$ & \\
\hline
\end{tabular}




\section{KESIMPULAN DAN SARAN}

\section{Kesimpulan}

Komponen kimia dari ekstrak ijuk dengan nheksana dapat menghambat aktivitas rayap dalam menaikkan persentase tingkat mortalitas rayap dan menurunkan laju konsumsi rayap.

\section{Saran}

Isolasi dan identifikasi komponen kimia yang bersifat aktif secara biologis terhadap rayap maupun organisme perusak kayu lainya perlu dilakukan.

\section{DAFTAR PUSTAKA}

Irfan. 2005. Efektivitas ijuk, Tempurung Kelapa, Tempurung Kemiri, Batu Gunung dan Tanah sebagai Perintang Fisik Alami Serangan Rayap Tanah pada Kayu. Skripsi Jurusan Kehutanan Unhas. Makassar (Tidak Dipublikasikan)

Martawijaya, A. 1996. Keawetan kayu dan Faktor yang Mempengaruhinya: Petunjuk Teknis. Pusat Penelitian dan Pengembangan Hasil Hutan dan Sosial Ekonomi Kehutanan. Bogor.

Rakhmawati. 1996. Prakiraan Kerugian Ekonomis Akibat Serangan Rayap pada Bangunan Perumahan di Indonesia. Skripsi Jurusan Teknologi Hasil Hutan. Fakultas Kehutanan IPB. Bogor (Tidak Dipublikasikan).

Sari, L. dan A.H. Sutjipto. 2003. Daya Racun Ekstraktif Kulit Pucung terhadap Rayap
Kayu Kering. Cryptotermes cynocephalus Light. Jurnal IImu dan Teknologi Kayu Tropis, 2(1) : 16-20.

Sari, R.K., W. Syafii, K. Sofyan dan M. Hanafi. 2003. Sifat Anti Rayap Resin Damar Mata Kucing dari Shorea javanica K.et V. Jurnal Ilmu dan Teknologi Kayu Tropis, 2(1) : 8-15.

Sastrodiharjo, S. 1999. Arah Pembangunan dan Strategi Penggunaan Pestisida Nabati. Makalah Disajikan pada Forum Komunikasi Pemanfaatan Pestisida Nabati, Balai Penelitian Tanaman Rempah dan Obat. 910 November. Bogor.

Soeseno, S. 1993. Bertanam Aren. Penebar Swadaya. Jakarta.

Supriana, N. 2002. Kajian Peran Pengawetan Kayu Perumahan dan Gedung dalam Rangka Pengelolaan Hutan Lestari. Laporan Hasil Penelitian (Tidak Dipublikasikan).

Takematsu, Y., T. Yoshimura, S.Yusuf, Y. Yanase, K.Kambara, A. Tashiro, S. Doi, M. Takeshi, P. Sukartana, T. Inoue, H. Yuzawa, M. Ohkuma, T. Kudo, Y.Sornnuwat, and C. Vongkaluang. 2006. Termite Assemlages in Urban Areas of South East Asia: Diversity and Economic Impacts. In: Sustainable Development and Utilization of Tropical Forest Resources (Ed: Y. Imamura et.al.). Report of JSPS-LIPI Core University Program in the Field of Wood Science 1995-2006. Kyoto. Japan. pp: 84-91.

Widianto, M.B. 1992. Obat Sintetik : Sintesis, Biotransformasi dan Analisis. Gadja Mada University Press. Yogyakarta.

Diterima : 17 Desember 2006

Astuti Arif dan Fatmawaty Samma

Lab. Keteknikan dan Diversifikasi Produk Hasil Hutan

Jurusan Kehutanan, Universitas Hasanuddin

Kampus Tamalanrea, Jl. Perintis Kemerdekaan Km. 10, Makassar 90245

Telp./Fax. 0411-585917. Indonesia

M. Natsir Usman

Balai Besar Industri Hasil Hutan

Jl. Racing Centre No. 28, Makassar 